\title{
MODEL KEPEMIMPINAN GURU SKI MTsN 9 SLEMAN DALAM MENINGKATKAN PRESTASI DAN MOTIVASI BELAJAR SISWA
}

\author{
Muklis Cahyo Muh Arifin \\ Universitas Islam Indonesia, Yogyakarta, Indonesia \\ 16422182@students.uii.ac.id
}

\section{Burhan Nudin}

Universitas Islam Indonesia, Yogyakarta, Indonesia burhannudin@uii.ac.id

DOI: 10.20885/tarbawi.vol13.iss1.art4

\begin{abstract}
This research originated from the emergence of students' negative views on learning SKI (Islamic Cultural History). The leadership role of SKI teachers is expected to provide learning motivation so that it can improve student achievement. The purpose of this study is to analyze the application of leadership and explain the constraints of implementing the leadership of the SKI teachers in increasing student achievement and motivation. This research use desciptive qualitative approach. Data collection techniques are by observation, interviews and documentation. The research informants consisted of the vice chairman, the SKI teacher, and three students. This study found that teacher leadership can increase learning achievement and motivation. The process of applying leadership in learning, namely; 1) The teacher's introduction always begins with greetings, prayers, and motivation; 2) The core activity of learning is to use learning methods with interesting media; 3) In the closing activity, the teacher asks about the material that has been delivered and works on questions from the teacher. The process of implementing leadership outside of teacher learning always provides good examples such as student discipline and morals. Constraints faced by common are such as students lack of discipline in participating in
\end{abstract}




\title{
$e^{\text {I-Tarbawj Mukhlis Cahyo Muh Arifin \& Burhan Nudin }}$
}

learning, diverse characters, new methods that do not necessarily give satisfactory results. Meanwhile, the special obstacles faced were the lack of learning hours for the SKI, the lessons that were less attractive to students, and the differences in the educational background of the students.

Keywords: Leadership, Achievement and Motivation, SKI Teachers, Students

\begin{abstract}
Abstrak
Penelitian ini berawal dari munculnya pandangan negatif siswa terhadap pembelajaran SKI (Sejarah Kebudayaan Islam). Peran kepemimpinan guru SKI diharapkan dapat memberikan motivasi belajar sehingga dapat meningkatkan prestasi belajar siswa. Tujuan penelitian ini untuk menganalisis penerapan kepemimpinan dan menjelaskan kendala-kendala pelaksanaan kepemimpinan guru SKI dalam meningkatkan prestasi dan motivasi siswa. Penelitian ini menggunakan pendekatan deskriptif kualitatif. Teknik pengumpulan data adalah dengan observasi, wawancara dan dokumentasi. Informan penelitian terdiri dari wakil ketua, guru SKI, dan tiga siswa. Penelitian ini menemukan bahwa kepemimpinan guru dapat meningkatkan prestasi dan motivasi belajar. Proses penerapan kepemimpinan dalam pembelajaran yaitu; 1) Perkenalan guru selalu diawali dengan salam, do'a, dan motivasi; 2) Kegiatan inti pembelajaran adalah menggunakan metode pembelajaran dengan media yang menarik; 3) Pada kegiatan penutup, guru menanyakan materi yang telah disampaikan dan mengerjakan soal dari guru. Proses pelaksanaan kepemimpinan di luar pembelajaran guru selalu memberikan contoh yang baik seperti kedisiplinan dan akhlak siswa. Kendala yang dihadapi umum adalah seperti siswa kurang disiplin dalam mengikuti pembelajaran, karakter yang beragam, metode baru yang belum tentu memberikan hasil yang memuaskan. Sedangkan kendala khusus yang dihadapi yaitu kurangnya jam pembelajaran SKI, pelajaran SKI yang kurang diminati oleh peserta didik, dan perbedaan latar belakang pendidikan peserta didik.
\end{abstract}


Kata kunci: Kepemimpinan, Prestasi dan Motivasi, Guru SKI, Peserta Didik

\section{Pendahuluan}

Pandangan peserta didik terhadap mata pelajaran Sejarah Kebudayaan Islam (SKI) dan materi pembelajaran SKI yang membahas cerita masa lalu dapat mengundang peserta didik tidak tertarik untuk mempelajarinya. Dalam pembelajaran SKI peserta didik dituntut untuk mampu menghafal nama tokoh, tempat sejarah, tanggal peristiwa, dan lain-lain. Informasi yang didapat peneliti dari guru SKI di MTs N 9 Sleman menyatakan bahwa pandangan peserta didik terhadap Sejarah Kebudayaan Islam kurang tertarik dalam mengikuti pembelajaran.

Salah satu kompetensi guru Pendidikan Agama Islam adalah menguasai Sejarah Kebudayaan Islam yang mana materi pembelajarannya membahas tentang cerita yang sudah terjadi di masa lampau dengan didasarkan kepada sumber nilai-nilai Islam. Dengan kepemimpinan, seorang guru akan membuat peserta didik lebih termotivasi dan mendorong prestasi peserta didik menjadi lebih baik. Pada sebuah pembelajaran yang berlangsung di kelas menggunakan metode cerita seharusnya menjadi sebuah ketertarikan tersendiri bagi para peserta didik dalam memahami pembelajaran.

Kompetensi guru yang dilihat dalam penelitian ini adalah kepemimpinan dan itu merupakan kompetensi yang wajib dimiliki oleh pendidik. Menurut Abdullah dalam proses pendidikan di sekolah yang terjadi, didominasi oleh proses belajar mengajar, bukan proses mendidik sehingga guru tidak 


\section{$e^{\text {I-Tarbawj Mukhlis Cahyo Muh Arifin \& Burhan Nudin }}$}

lagi sebagai pendidik yang membimbing untuk mencapai kedewasaan rohaniah, tetapi berfungi sebagai pengajar yang mengejar target kurikulum dalam bentuk sejumlah materi pelajaran (Burhanuddin 2010, 07). Menurut peraturan Kemenag, guru Pendidikan Agama adalah guru harus memiliki kompetensi pedagogik, kepribadian, sosial, profesional, dan kepemimpinan (Permenag 2010). Peran kepemimpinan guru menjadi sentral kedua setelah kepala sekolah di dalam mengarahkan perubahan. Guru mempunyai banyak peran dalam dunia pendidikan, diantaranya sebagai informator, korektor, inspirator, motivator, fasilitator, organisator, inisiator, pembimbing, demonstrator, mediator, supervisor, pengelola kelas, dan evaluator (Syaiful 2005, 43).

Dalam mencapai keberhasilan suatu pembelajaran tidak terlepas dari peran guru dan peserta didik. Pembelajaran dikatakan berhasil jika peserta didik mendapatkan hasil yang memuaskan. Ada banyak faktor untuk mencapai hasil belajar peserta didik dengan maksimal, salah satu faktornya yaitu kepemimpinan guru. Menurut Badeni kepemimpinan didefinisikan sebagai kemampuan seseorang untuk mempengaruhi suatu kelompok ke arah tercapainya tujuan (Badeni 2013, 03). Peran kepemimpinan guru sangat dominan mempengaruhi hasil belajar peserta didik. Dengan diterapkannya kepemimpinan, guru akan membuat termotivasi peserta didik sehingga prestasi belajar peserta didik memuaskan. Dalam implementasinya di sekolah MTs N 9 Sleman, peran kepemimpinan guru SKI sudah diterapkan, dengan membuat pembelajaran SKI aktif, inovatif, kreatif, efektif dan menyenangkan. Dibuktikan dengan guru 
mempersiapkan membuat rencana pelaksanaan pembelajaran (RPP), yang mana fungsinya untuk acuan bagi guru untuk melaksanakan kegiatan belajar mengajar agar lebih terarah dan berjalan secara efektif dan efisien (Kunandar 2011, 264).

Dari latar belakang di atas melalui pra pengamatan peneliti, senyatanya bahwa pandangan peserta didik terhadap mata pelajaran Sejarah Kebudayaan Islam di MTs N 9 Sleman cenderung menghindari, menjauhi dan perasaan tidak suka atau tertarik dalam mengikuti pembelajaran. Seharusnya, peran kepemimpinan guru SKI diharapkan bisa memberikan motivasi belajar peserta didik dengan begitu akan dapat meningkatkan prestasi belajar dalam pembelajaran Sejarah Kebudayaan Islam. Dengan demikian menjadi salah satu alasan peneliti untuk mengkaji lebih dalam tentang penerapan kepemimpinan guru SKI dalam meningkatkan prestasi dan motivasi belajar peserta didik.

Tujuan dari penelitian ini adalah untuk mengetahui dan mendeskripsikan penerapan kepemimpinan guru Sejarah Kebudayaan Islam dalam meningkatkan prestasi dan motivasi belajar peserta didik. Kemudian untuk mengetahui dan menjelaskan kendala yang dihadapi untuk penerapan kepemimpinan guru Sejarah Kebudayaan Islam dalam meningkatkan prestasi dan motivasi belajar peserta didik. Hal inilah yang membuat peneliti ingin membuktikan terkait penerapan kepemimpinan guru Sejarah Kebudayaan Islam dalam meningkatkan prestasi dan motivasi belajar peserta didik di MTs N 9 Sleman. 


\section{$e^{\text {I-Tarbawj Mukhlis Cahyo Muh Arifin \& Burhan Nudin }}$}

\section{Metode Penelitian}

Penelitian ini merupakan penelitian deskriptif dan dengan jenis deskriptif kualitatif. Penelitian deskriptif kualitatif merupakan sebuah metode penelitian yang memanfaatkan data kualitatif dan dijabarkan secara deskriptif (Sugiyono 2017, 207). Tempat penelitian berlokasi di MTs Negeri 9 Sleman. Data-data yang diperoleh melalui observasi, wawancara dan dokumentasi. Wawancara yang dilakukan meliputi wakil kepala madrasah, guru mata pelajaran Sejarah Kebudayaan Islam dan peserta didik. Observasi dilakukan dengan dua cara, observasi pra penelitian dan observasi setelah penelitian. Sedangkan dokumentasi didapatkan melalui arsip-arsip sekolah dan juga melihat web sekolah yang tersedia di internet yang diperbarui secara berkala tiap tahunnya. Penentuan informan dalam penelitian ini dilakukan dengan teknik purposive sampling, di mana peneliti menentukan pengambilan sampel dengan cara menetapkan berdasarkan ciri-ciri khusus yang sesuai dengan tujuan penelitian sehingga diharapkan bisa menjawab permasalahan penelitian.

\section{Hasil dan Pembahasan}

Penerapan kepemimpinan guru Sejarah Kebudayaan Islam dalam pembelajaran untuk meningkatkan prestasi dan motivasi peserta didik menggunakan tipe kepemimpinan demokratis. Tipe kepemimpinan demokratis selalu mendahulukan kepentingan organisasinya dari pada kepentingan individu. Dijelaskan dalam hasil wawancara 
dengan guru SKI bahwa beliau lebih mengutamakan kepentingan siswa dari pada kepentingan lain saat dalam jam efektif mengajar. Dalam mengambil keputusan atau pendapat tipe kepemimpinan dekomkratis selalu mengambil keputusan bersama. Dalam hasil observasi pengambilan keputusan, guru SKI tidak semena-mena dengan bermusyawarah dan mengambil keputusan bersama dengan menyesuaikan keinginan peserta didik dan dengan mempertimbangkan kesanggupan peserta didik.

\section{Penerapan Kepemimpinan Guru SKI dalam Meningkatkan Motivasi dan Prestasi Belajar Peserta Didik}

Dari hasil penelitian yang telah peneliti lakukan di MTs N 9 Sleman, penerapan kepemimpinan guru Sejarah Kebudayaan Islam dengan tipe kepemimpinan demokratis adalah untuk meningkatkan prestasi dan motivasi belajar peserta didik. Kepemimpinan merupakan suatu usaha yang dilakukan guru Sejarah Kebudayaan Islam untuk mempengaruhi peserta didik agar mau belajar dan semangat belajar guna mencapai tujuan pendidikan yang telah ditetapkan. Adapun proses penerapan kepemimpinan guru Sejarah Kebudayaan Islam adalah dengan kepemimpinan demokratis untuk meningkatkan pretasi dan motivasi belajar peserta didik

Peran kepemimpinan guru dengan tipe kepemimpinan demokratis bisa dijadikan salah satu strategi untuk meningkatkan motivasi belajar peserta didik. Tentu pasti ada hal-hal yang dapat mempengaruhi motivasi belajar peserta didik. Seperti halnya perfoman guru yang tidak bisa 


\section{$e^{\text {I-Tarbawj Mukhlis Cahyo Muh Arifin \& Burhan Nudin }}$}

dipungkiri. Berikut hasil wawancara peneliti dengan seorang guru, Elva, sebagai waka humas.

Memang perfoman dari guru bersangkutan merupakan salah satu kunci untuk anak itu bisa tertarik dengan hal seperti itu. Kemudian model mengajarnya atau model pembelajarannya begitu juga dengan medianya atau alat peraganya.

Dari data di atas jelas bahwa perfoma guru tidak dapat dipungkiri karena ini merupakan salah satu hal yang dapat meningkatkan motivasi belajar. Jika perfoma guru biasa-biasa saja maka peserta didik juga akan mengikutinya dengan biasabiasa saja. Berbeda dengan guru mengajar dengan perfoman yang baik yang penuh semangat maka peserta didik akan semangat mengikut pembelajaran karena termotivasi dengan performa guru yang luar biasa. Dari hasil observasi peneliti bahwa guru Sejarah Kebudayaan Islam menggunakan media pembelajaran yang menarik yaitu menggunakan media pembelajaran dengan power point, film, dan lain-lain.

Dari hasil penelitian, peneliti menemukan indikatorindikator meningkatnya motivasi peserta didik di MTs N 9 Sleman dalam pembelajaran Sejarah Kebudayaan Islam seperti tekun dalam mengerjakan tugas, tidak cepat bosan dalam pembelajaran, dan ulet dalam proses pembelajaran.

Sebagai sebuah ukuran dan memberikan motivasi kepada siswa guru mengajak siswa selalu aktif dalam pembelajaran, diajak untuk memberikan setiap kreatifitasnya dalam belajar dan yang paling utama adalah menjadikan kelas tempat yang nyaman dengan media, metode dan materi agar terlahirnya motivasi belajar yang tinggi dari siswa supaya apa yang 
diajarkan bisa dipahami dan dapat diamalkan. Sementara menurut siswa dalam motivasi belajar, sebagai salah satu faktor yang mampu mempengaruhi prestasi belajar sehingga dengan adanya motivasi maka siswa akan belajar lebih keras, ulet, tekun, dan dapat memiliki konsentrasi yang penuh dalam proses belajar pembelajaran.

\section{Kepemimpinan dalam Proses Pembelajaran}

Upaya proses penerapan kepemimpinan guru sejarah kebudayaan Islam saat pembelajaran dengan tipe kepemimpinan demokratis untuk meningkatkan prestasi belajar peserta didik dengan berbagai langkah-langkah. Mulai dari pendahuluan yaitu seperti sebelum memulai pembelajaran, guru Sejarah Kebudayaan Islam selalu menanyakan kabar peserta didik kondisi apakah baik-baik saja, menanyakan kesulitan apa saja dalam pembelajaran, menanyakan hal-hal yang lainnya guna untuk membuat rasa nyaman peserta didik, kemudian memotivasi sebelum memulai pembelajaran dan yang terakhir guru selalu mengecek apakah peserta didik sudah siap mengikuti pembelajaran Sejarah Kebudayaan Islam. Guru SKI menyatakan bahwa pembalajaran yang baik adalah yang diawali dengan pembukaan yang didalamnya menyampaikan tujuan pada pembelajaran tersebut. Sehingga ini bisa terlihat hasilnya baik secara langsung atapun tidak.

Yang kedua adalah kegiatan inti yaitu guru sering membuat metode pembelajaran yang menarik seperti menggunakan media pembelajaran agar membuat lebih 


\section{$e^{\text {I-Tarbawj Mukhlis Cahyo Muh Arifin \& Burhan Nudin }}$}

maksimal dalam memberikan materi pembelajaran. Dari hasil wawancara dengan guru SKI untuk metode yang diterapkan harus menarik dan menyenangkan agar siswa lebih senang belajar Sejarah Kebudayaan Islam. Sehingga diharapkan peserta didik dapat lebih mudah memahami penjelasan yang disampaikan guru dan bisa diterima peserta didik. Dari hasil wawancara peneliti dengan peserta didik bahwa mereka merasa nyaman saat pembelajaran Sejarah Kebudayaan Islam karena guru menyampaikan materinya dengan menggunakan media power point yang menarik sehingga tidak membuat bosan saat pembelajaran berlangsung. Dari dokumentasi yang didapat peneliti bahwa media yang menarik dan unik menjadi salah satu strategi guru untuk membangkitakan minat dan rasa ingin tahu peserta didik sehingga akan senang dalam belajar Sejarah Kebudayaan Islam. Adapun strategi-strategi yang dapat dengan mudah memahamkan materi yang disampaikan kepada peserta didik, dari hasil wawancara dengan seorang guru, Herni.

Yang pertama menggunakan metode dalam pembelajaran yang beragam dengan menyesuaikan materi Sejarah Kebudayaan Islam dengan metode dan medianya agar siswa dapat dengan mudah memahami materi yang disampaikan. Yang kedua siswa diajak untuk aktif dalam proses pembelajaran. Yang ketiga membuat tugas yang mengajarkan peserta didik tertantang dan bisa mengarahkan pada pemahaman materi yang realistis. kemudian menciptakan suasana kelas yang kondusif dan menyenangkan di dalam kelas dan memberikan tugas sesuai dengan materi dan secara proporsionnal sesuai KD yang ada, terus juga melibatkan guru aktif langsung 
untuk membimbing dan membantu peserta didik untuk mencapai hasil yang maksimal. Kemudian selanjutnya memberikan petunjuk kepada peserta didik agar sukses dalam belajar, menghindarkan peserta didik untuk berkompetisi antar pribadi yang mengakibatkan prilaku yang negatif dengan memberikan ide-ide dan masukan kepada peserta didik untuk belajar lebih rajin dan menyukai pelajaran Sejarah Kebudayaan Islam agar pelajaran Sejarah Kebudayaan Islam menjadi pelajaran favorit. Yang terakhir Memberikan motivasi dan penghargaan kepada siswa yang mendapat nilai sesuai KKM atau nilai di atas KKM dan menghindari komentar buruk yang menjatuhkan semangat dan sebaiknya memberikan semangat yang baik.

Yang ketiga adalah kegiatan penutup sebelum pembelajaran selesai peserta didik diingatkan kembali materi yang sudah disampaikan dan terakhir peserta didik mengerjakan kumpulan soal dari guru. Guru mempunyai cara untuk meningkatkan prestasi belajar peserta didik. Hasil wawancara menunjukan bahwa pada bagian penutupan pembelajaran yang berlangsung yaitu guru memberikan soalsoal dengan cara yang berbeda-beda seperti games ataupun secara tertulis.

Dalam hasil observasi, penerapan kepemimpinan dalam pembelajaran ada tolak ukur keberhasilan peserta didik dalam menerima materi yang telah diberikan guru. Berikut hasil wawancara dengan seorang guru, Herni, yang memaparkan tolak ukur pada pembelajaran SKI yang berlangsung yaitu:

Untuk masalah tolok ukur jadi gini mas, saya sebagai guru dalam memberikan materi di kelas dengan creative dan innovative dengan langkah-langkah. Pertama saya 


\section{el-Tarbawj Mukhlis Cahyo Muh Arifin \& Burhan Nudin}

membuat persiapan dalam menyampaikan materi di kelas secara sitematis dengan membuat metode yang tepat dan sesuai dengan materi yang akan disampaiakan agar murid tidak bosan belajar di kelas dan bervariasi dalam peyampaiannya, dari media atau metodenya sehingga pembelajaran di kelas menjadi berkualitas. Kemudian yang kedua dalam mengajar saya menggunakan suara yang keras sehingga terdengar siswa dalam satu kelas. Yang ketiga kegiatan kelas harus efektif tidak bertele-tele dan saya harus bisa menguasai kelas, diupayakan kelas tidak ramai dan tidak gaduh sehingga dapat memecah konsentrasi siswa atau guru selama pembelajaran Sejarah Kebudayaan Islam di kelas. Yang terakhir berusaha untuk selalu memotivasi siswa agar belajar dengan rajin dan tekun agar dapat mewujudkan prestasi, melakukan hubungan yang interactive terhadap siswa dalam proses pembelajaran misalnya dengan menanyakan bagaimana kesiapan siswa untuk mengikuti pembelajaran, setelah penyampaian materi apakan siswa sudah memahami materi dan memberikan penguatan materi agar siswa lebih memahami materi Sejarah Kebudayaan Islam.

Dari hasil penelitian, tolak ukur yang guru lakukan adalah dengan memberikan penilaian pengetahuan dan keterampilan peserta didik sejauh mana materi pembelajaran SKI mampu dipahami.

Data yang didapat di atas, peneliti jadikan sebagai tolak ukur untuk mengukur keberhasilan guru SKI dalam meningkatkan prestasi belajar peserta didik. Karena peneliti tidak mengukur peningkatan prestasi belajar dengan pre test dan post test untuk mengevaluasi dengan mengukur kompetensi awal dan kompetensi akhir peserta didik. Peneliti 
mengevaluasi kompetensi awal dan kompetensi akhir peserta didik dengan melihat hasil nilai pembelajaran dari awal hingga akhir pembelajaran yaitu dengan melihat nilai rata-rata SKI dari mulai bab satu hingga bab empat. Sehingga peneliti bisa menarik kesimpulan apakah guru SKI dengan jiwa kepemimpinannya bisa meningkatkan prestasi siswa.

\section{Proses di Luar Pembelajaran}

Dari hasil penelitian, peneliti menemukan indikatorindikator meningkatnya motivasi peserta didik di MTs N 9 Sleman dalam pembelajaran Sejarah Kebudayaan Islam seperti tekun dalam mengerjakan tugas, tidak cepat bosan dalam pembelajaran dan ulet dalam proses pembelajaran yang kesemua itu sebagai sebuah ukuran dan memberikan motivasi kepada siswa. Guru mengajak siswa selalu aktif dalam pembelajaran, diajak untuk memberikan setiap kreativitasnya dalam belajar dan yang paling utama adalah menjadikan kelas sebagai tempat yang nyaman dengan media, metode dan materi agar terlahirnya motivasi belajar yang tinggi dari siswa supaya apa yang diajarkan bisa dipahami dan dapat diamalkan.

Kendala dalam Penerapan Kepemimpinan Guru SKI dalam Meningkatkan Prestasi dan Motivasi Belajar Peserta Didik

Dari hasil penelitian didapati bahwa kendala pada umumnya seperti karakter dan minat bakat siswa, sehingga diperlukan kemampuan dan manajemen yang baik agar bisa mengarahkan semua siswa. Sama halnya dengan pembelajaran 


\section{$e^{\text {I-Tarbawj Mukhlis Cahyo Muh Arifin \& Burhan Nudin }}$}

yang lain yaitu dalam proses penerapan kepada siswa seperti mempunyai siswa yang kurang disiplin ketika mengikuti pembelajaran di kelas. Menurut salah satu guru, Elva, kendala penerapan kepemimpinan guru SKI dalam meningkatkan prestasi dan motivasi belajar yaitu:

"Dalam pembelajaran pasti ada inovasi terbaru terkait metode pembelajaran agar siswa tidak merasah bosan dengan metode itu-itu saja."

Metode pembelajaran yang baru belum tentu memberikan hasil yang memuaskan. Adapun kendala yang terjadi di metode pembelajaran baru yaitu belum bisa memberikan pemahaman secara sepenuhnya kepada siswa sehingga yang terjadi adalah siswa susah memahami pembelajaran Sejarah Kebudayaan Islam. Seperti yang disampaikan peserta didik bahwa materi pembelajaran tidak semuanya terserap karena penjelasan yang diberikan guru tertulis sulit untuk dipahami.

Menurut peserta didik bahwa siswa yang susah memahami materi Sejarah Kebudayaan Islam dalam pembelajaran ketika diberi tugas masih banyak yang tidak mengerjakan walaupun sudah diberikan waktu yang cukup lama.

Dari hasil observasi peneliti ada berbagai kendala-kendala yang dihadapi guru Sejarah Kebudayaan Islam dalam pembelajaran beserta kendala yang dihadapi guru Sejarah Kebudayaan Islam dalam meningkatkan prestasi dan motivasi belajar peserta didik seperti kurangnya jam pembelajaran SKI, pelajaran Sejarah Kebudayaan Islam yang kurang diminati, dan perbedaan latar belakang pendidikan. 
Guru profesional harus mampu menghadapi kendalakendala yang ada dengan cara bijak. Pemecahan masalah harus dengan memahami masalah yang ada dengan tingkat kesulitannya. Menurut seorang Guru, Elva, solusi dalam menyelesaikan permasalahan pembelajaran guru yang bersangkutan harus belajar atau diskusi dengan guru semata pelajaran atau istilah lainnya studi banding dengan guru SKI di MTs lain.

Penerapan Kepemimpinan Guru Sejarah Kebudayaan Islam dalam Meningkatkan Prestasi dan Motivasi Belajar Peserta Didik

Kepemimpinan guru SKI sangat memberikan dampak sangat baik terhadap peserta didik. Dari hasil penelitian yang dilakukan, guru tidak hanya menjadi central learning yang berdampak pada satu arah pembelajaran. Sehingga peneliti menggunakan pendapat dari Burt Nanus yang menjelaskan peran kepemimpinan yang sangat efektif ada empat yang harus diterapkan (Werren \& Burt Nanus 2006, 03). Pertama, pemberi arah. Seorang pemimpin diharapkan harus mampu memberikan arahan atau pengarahan kepada bawahannya. Tujuannya untuk mempengaruhi bawahannya agar terkondisikan dalam melaksanakan dan menyelesaikan semua tugasnya. Seorang pemimpin harus mampu melakukan pengerahan seluruh sumber daya organisasi dalam mencapai visi sekolah. Pemimpin yang dapat berperan sebagai penentu arah adalah pemimpin visioner (Burt Nanus 2001, 95).

Kedua, agen perubahan. Pemimpin harus memberikan motivasi dan peluang kepada bawahannya agar bisa memberikan inovasi perubahan mulai dari yang terkecil. Dan 


\section{$e^{\text {I-Tarbawj Mukhlis Cahyo Muh Arifin \& Burhan Nudin }}$}

untuk menjawab tantangan kedepan dan demi menetapkan tujuan serta kesuksesan maka seorang pemimpin harus membuat visi dan misi dalam sebuah lembaga. Ketiga, pembicara. Sebagai pemimpin yang memimpin jalannya rapat ataupun diskusi maka menggunakan teknik bicara dengan kalimat yang sopan dan mudah dipahami oleh orang lain. Hindari kata-kata kasar karena akan memberikan penilaian negatif kepada yang mendengarkannya. Jadilah seseorang pemimpin yang berwibawa dan percaya diri dengan apa yang sudah dikatakan. Saat akan berbicara dengan banyak orang maka ubahlah teknik berbicara dengan menyempaikann pesan dengan sesingkat mungkin agar menjadi lebih sederhana dan mudah dimengerti oleh semua orang yang sedang memperhatikan. Keempat, pembina. Pemimpin berperan sebagai mentor yang menjadikan visi menjadi realitas. Pemimpin memberdayakan bawahaannya dalam organisasinya serta mengarahkan prilaku mereka agar sesuai dengan visi yang telah dirumuskan disebut dengan pembina. Pemimpin juga harus memberitahu orang lain tentang realita saat ini, apa visinya atau ke mana tujuan, bagaimana merealisasikannya (Komariah 2008, 93).

Peranan menurut Levinson sebagai mana dikutip oleh Soejono Soekanto suatu konsep prihal apa yang dapat dilakukan individu peserta didik yang penting bagi struktur sosial di sekolah maupun masyarakat yang meliputi normanorma yang dikembangkan. Peranan dalam arti ini merupakan rangkaian peraturan-peraturan yang membimbing seseorang atau peserta didik dalam kehidupan kemasyarakatan (Soerjono Soekanto 2006, 238). Teori yang dikemukakan di atas 
merupakan standar yang peneliti gunukan untuk melihat peran merupakan kepemimpinan yang efektif. Dari hasil penelitian menunjukan bahwa peran kepemimpinan guru SKI dalam meningkatkan motivasi dan prestasi siswa seperti, pertama, memberikan pengarahan yang baik tehadap peserta didik; kedua, selalu memberikan motivasi dan inovasi terhadap peserta didik, sebagai pembicara yang baik berupa kata-kata yang baik agar pembicaraan yang baik tersebut bisa dijadikan panutan dari peserta didik itu sendiri; ketiga, selain itu guru selaku mentor dan problem solver membina dan mengarahkan peserta didik untuk berprestasi dan memberikan motivasi yang belajar kepada peserta didik.

Dari hasil penelitian kemudian dianalisis dengan teori menurut Burt Nanus dapat disimpulkan bahwa hasil dari penelitian sama dengan teori Burt Nanus, yaitu dari peran kepemimpinan guru yang efektif adalah selalu mengarahkan peserta didik menuju ke arah kebaikan, baik berupa perkataan dan perbuatan yang dilakukan. Yang paling utama dari peran kepemimpinan guru yang efektif adalah selalu mengarahkan dan membimbing peserta didik menuju ke arah kebaikan, baik berupa perkataan dan perbuatan yang dilakukan. Sehingga pada penerapannya guru SKI memberikan peran kepemimpinan yang efektif di kelas dan dampak dari penerapan ini adalah siswa menjadi termotivasi dan hasil yang dicapai adalah prestasi baik di dalam kelas maupun di luar kelas.

Menurut Ordway Tead metode kepemimpinan terdiri dari delapan yaitu memberi perintah, memberi celaan, memberi pujian, memberikan tingkah laku pribadi, menciptakan disiplin 


\section{$e^{\text {I-Tarbawj Mukhlis Cahyo Muh Arifin \& Burhan Nudin }}$}

diri dan kelompok, dan menentramkan kabar angin yang tidak bener (Indah Nurhayati 2018, 18). Didapati oleh peneliti di lapangan terkait dengan penerapan kepemimpinan guru Sejarah Kebudayaan Islam dalam meningkatkan prestasi dan motivasi belajar adalah menggunakan metode yang menarik dan beragam ketika proses pembelajaran yaitu; Pertama, mengajak untuk aktif dalam pembalajaran; Kedua, memberikan tugas yang sesuai dengan kemampuan siswa; Ketiga, menciptakan susanana kelas yang asyik dan menyengankan; Keempat, selalu memberikan motivasi dan semangat belajar kepada siswa agar menjadi siswa yang berprestasi dan berakhlakul karimah; Kelima, memberikan penghargaan kepada siswa yang berprestasi dan jika belum maka dirangkul dan diajarkan serta selalu memotivasi.

Analisis peneliti menunjukan bahwa guru sudah semaksimal mungkin menggunakan metode yang menarik dan beragam agar ketika proses pembelajaran peserta didik tidak cepat merasa bosan. Dari hasil penelitian dengan teori, guru sudah menggunakan metode yang menarik sehingga disimpukan teori yang dipakai dan hasil yang ditemukan hampir sama.

Dari metode pembelajaran yang digunakan dalam pembelajaran pada penerapan kepemimpinan, guru Sejarah Kebudayaan Islam meningkatkan prestasi dan motivasi belajar. Peneliti menemukan bahwa pada pembelajaran Sejarah Kebudayaan Islam guru menggunakan gaya kepemimpinan demokratis. Tipe kepemimpinan demokratis selalu mendahulukan kepentingan organisasinya dari pada kepentingan individu. Menurut Purwanto bahwa 
kepemimpinan demokratis yaitu pemimpin yang partisipatif berkonsultasi dengan bawahan tentang tindakan dan keputusan yang diusulkan serta mendorong adanya keikutsertaan bawahan (Purwanto 2004, 49). Kepemimpinan demokratis menurut Rivai ditandai dengan adanya suatu struktur yang pengembangannya menggunakan pendekatan pengambilan keputusan yang kooperatif (Rivai 2009, 61). Kepemimpinan demokratis dianggap kepemimpina yang terbaik, sebab kepemimpinan ini berorientasi dan memberikan bimbingan yang efesien kepada seluruh bawahannya. Setiap orang yang memiliki kemampuan, minat, pikiran, perhatian, serta pendapat yang berbeda antara satu dengan yang lain akan sangat dihargai dan dihormati oleh pimpinannya didalam tipe kepemimpinan demokratis.

Indikator gaya kepemimpinan demokratis menurut Pasolong dalam Ariani diantaranya adalah: Pertama, keputusan dibuat bersama; Kedua, menghargai potensi setiap bawahannya; Ketiga, Mendengar kritik, saran/pendapat dari bawahan; Keempat, melakukan kerjasama dengan bawahannya (Ariani 2015, 10).

Adapun hasil dari penelitian, indikator kepemimpinan guru yang peneliti temukan dalam penelitian sebagai berikut; Pertama, guru SKI dalam mengambil keputusan bersama antara guru da peserta didik; Kedua, guru SKI menempatkan posisinya tidak sebagai subjek pembelajaran tetapi juga menjadi objek dalam pembelajaran; Ketiga, guru SKI selalu menerima masukan dari peserta didik dan guru menghargai.

Dari hasil analisis teori, indikator kepemimpinan dengan hasil penelitian maka dapat disimpulkan bahwa guru 


\section{$e^{\text {I-Tarbawj Mukhlis Cahyo Muh Arifin \& Burhan Nudin }}$}

menggunakan tipe kepemimpian demokratis dalam pembelajaran untuk meningkatkan prestasi dan motivasi belajar peserta didik. Dari teori dan hasil penelitian menunjukkan hasil yang sama antara teori dengan hasil penelitian. Jadi guru SKI dalam pembelajaran menggunakan tipe kepemimpinan demokratis. Pada penerapan yang dilakukan guru tidak menempatkan posisinya sebagai subjek pembelajaran tetapi juga menjadi objek dalam pembelajaran sehingga dalam memberikan pembelajaran guru sangat demokratis. Untuk itu diperlukan sebuah wadah yang baik berupa kurikulum yang baku agar hal tersebut bisa terlaksana dengan baik dan berjalan lama.

Selain itu dorongan prestasi dan motivasi belajar juga menjadi acuan dalam penelitian ini sehingga dalam sebuah pembelajaran harus mempunyai standar dalam penerapan prestasi belajar pendidikan. Hasil pengukuran peserta didik dengan melihat nilai rata-rata akademik pada pembelajaran Sejarah Kebudayaan Islam. Menurut Mager, Grounlund, dan Bloom merumuskan bahwa setiap kecerdasan ranah kogitif memiliki domain yang berbeda (Harsanto 2007, 95). Dari hasil penelitian dapat disumpulkan bahwa penerapan kepemimpinan guru dapat meningkatkan prestasi belajar peserta didik di MTs N 9 Sleman. Dilihat dari nilai rata-rata SKI peserta didik dari bab 1 sampai bab 4 adanya peningkatan prestasi akademik peserta didik walaupun masih ada juga ratarata nilai yang masih sama tapi setidaknya nilai rata-rata peserta didik masih bertahan dan tidak mengalami penurunan.

Peserta didik yang sudah berprestasi maka harus dikuatkan juga dengan motivasi belajar. Menurut Sardiman 
motivasi belajar adalah daya penggerak didalam diri individu peserta didik maupun di luar diri individu peserta didik untuk menimbulkan, memberi arahan dan menjamin terdapat kelangsungan kegiatan belajar, sehingga tujuan yang dikehendaki siswa dapat tercapai (Sardiman 2011, 73-74). Menurut Hamzah motivasi belajar dapat timbul karena faktor intrinsik dan ekstrinsik. Faktor intrinsik yang mempengaruhi motivasi belajar seperti hasrat, dorongan kebutuhan belajar, dan harapan akan cita-cita. Sedangkan faktor ekstrinsik yang mempengaruhi motivasi belajar meliputi adanya penghargaan, lingkungan belajar, dan kegiatan belajar yang menarik (Hamzah 2011, 23). Adapun ciri-ciri peserta didik termotivasi menurut Sardiman A.M, motivasi yang ada pada diri setiap orang itu memiliki ciri-ciri sebagai berikut; tekun menghadapi tugas, ulet menghadapi kesulitan, menunjukkan minat terhadap bermacam-macam masalah, lebih senang bekerja mandiri, cepat bosan pada tugas yang diulang-ulang, dapat mempertahankan pendapatnya, tidak mudah melepaskan hal yang diyakini, dan senang mencari dan memecahkan masalah (Sardiman 2011, 83).

Jika mengacu pada hasil penelitian yang menjelaaskan bahwa dalam pembelajaran SKI telah memberikan motivasi belajar yang baik kepada peserta didik namun belum bisa dimaksimalkan dengan sempurna. Namun Dari hasil penelitian, peneliti menemukan indikator-indikator meningkatnya motivasi peserta didik di MTs N 9 Sleman dalam pembelajaran Sejarah Kebudayaan Islam seperti; Pertama, tekun dalam mengerjakan tugas. Peserta didik sudah tekun dalam mengerjakan tugas dilihat dari hasil nilai rata-rata 


\section{$e^{\text {I-Tarbawj Mukhlis Cahyo Muh Arifin \& Burhan Nudin }}$}

Sejarah Kebudayaan Islam peserta didik sudah baik dalam memahami materi yang sudah diberikan. Kedua, idak cepat bosan dalam pembelajaran. Peserta didik bahwa guru Sejarah Kebudayaan Islam ketika dalam pembelajaran menggunakan media yang menarik akan membuat peserta didik tidak akan merasa cepat bosan dalam pembelajara; Ketiga, ulet dalam proses pembelajaran. Sebagai sebuah ukuran dan memberikan motivasi kepada siswa guru mengajak siswa selalu aktif dalam pembelajaran, di ajak untuk memberikan setiap kreatifitasnya dalam belajar dan yang paling utama adalah mejadikan kelas adalah tempat yang nyaman dengan media, metode dan materi agar terlahirnya motivasi belajar yang tinggi dari siswa supaya apa yang diajarkan bisa dipahami dan dapat diamalkan.

Dari fakta yang ditemukan menunjukan bahwa penerapan motivasi jika dilihat dari teori yang dipakai sebelumnya maka didapati bahwa penerapan motivasi belum secara maksimal namun menurut peneliti dari ketiga fakta tersebut menunjukan bahwa dalam penerapannya telah dilakukan dengan baik.

Kendala Penerapan Kepemimpinan Guru SKI dalam Meningkatkan Prestasi dan Motivasi Belajar Peserta Didik.

Proses pembelajaran di sekolah pasti memiliki kendala dalam pembelajaran. Kowalski dkk menguraikan faktor-faktor yang mempengaruhi kepemimpinan adalah individu, organisasi dan sosial. Keputusan yang diambil individu itu tidaklah murni disebabkan oleh kehendak peserta didik, tetapi bisa dipengaruhi dari faktor organisasi maupun sosial (Kowalski 2007, 25). Sebuah proses pembelajaran yang terjadi di sekolah pasti memiliki kendala baik itu secara besar maupun 
kecil. Seperti yang terjadi pada penerapan kepemimpinan guru SKI dalam meningkatkan prestasi dan motivasi belajar. Kendala kepemimpinan guru SKI dalam pembelajaran berdasarkan formula Hersey dan Blanchard serta penjelasan yang dikemukakan Kowalski dkk bahwa adanya faktor yang mempengaruhi yaitu faktor internal dan ekternal. Faktor internal guru tidak memiliki karakter yang unik atau perfoman yang bagus. Faktor eksternal disebabkan karakter bawaan peserta didik, karakter peserta didik yang berbeda-beda, dan faktor dari aspek situasi yang berkaitan dengan waktu, tempat, dan tujuan (Kowalski 2007, 25-26).

Kendala kepemimpinan guru dalam pembelajaran menurut Sidjabat ada lima (Sidjabat 1993, 11-14). Pertama, kegagalan berkomunikasi. Tersampainya ilmu atau materi kepada peserta didik, sebagai guru dituntut untuk dapat berkomunikasi dengan baik kepada peserta didik. Komunikasi merupakan bagian dari penyampaian informasi kepada orang lain dengan maksud dan tujuan yang dihendaki. Supaya apa yang disampaikan dapat dimengerti peserta didik maka guru hars menjelaskan dengan komunikasi dengan sebaik-baiknya (Widjaja 2002,10). Komunikasi memiliki peran untuk memberikan sebuah pengertian kepada orang lain secara beruntut. Komunikasi efektif sangat sulit karena dibutuhkan komitmen.

Kedua, ketegangan atau stres. Seorang pemimpin harus cepat tanggap terhadap stres yang dialaminya sendiri maupun oleh peserta didik. Stres menurut Bartsch dan Evelyn dalam Kholidah dan Alsa adalah ketegangan, beban yang menarik seseorang dari segala penjuru, tekanan yang dirasakan pada 


\section{$e^{\text {I-Tarbawj Mukhlis Cahyo Muh Arifin \& Burhan Nudin }}$}

saat menghadapi tuntutan atau harapan yang menantang kemampuan seseorang untuk mengatasi atau mengelola hidup. Dalam tahap tertentu, stres itu berguna bahkan diperlukan (Kholidah \& Alsa 2010, 69). Tetapi, stres yang berlebihan akan membuat segalanya kacau balau. Setiap orang berbeda dalam daya tahan terhadap suatu ketegangan, dan masing-masing memunyai reaksi yang berbeda terhadap ketegangan.

Ketiga, kurang siap dalam menghadapi arus perubahan. Dunia dan perubahannya sekarang ini berjalan begitu cepat sehingga kalau kita tidak segera membuat penyesuaian, maka kita akan ketinggalan. Bahkan kita semua sekarang ini merasakan perubahan yang sangat cepat dalam dunia pendidikan. Sekarang belajar tidak harus kepada guru, kita bisa belajar menggunakan internet. informasi yang didapat diinternet bahkan lebih luas dari pada guru. Di sini lah peran guru tidak hanya menyampaikan ilmu melainkan lebih dari itu seperti membentuk karakter anak untuk lebih baik.

Keempat, gagal memberikan motivasi. Kurangnya motivasi peserta didik akan membuat tidak semangat memperhatikan guru ketika sedang menjelaskan materi. Keberhasilan dalam proses pembelajaran tergantung pada guru sejauh mana bisa membangkitkan motivasi belajar peserta didik. Motivasi sangatlah penting dalam proses belajar mengajar, karena motivasi mendorong semangat belajar peserta didik.

Kelima, kurangnya sarana dan prasarana. Kurang terpenuhinya fasilitas pendidikan menimbulkan peserta didik susah untuk memahami pembelajaran dengan mudah. Minimnya sarana ini menyebabkan peserta didik yang hanya 
mengandalkan teori tanpa adanya realisasi yang nyata dalam belajar.

Peneliti membagikan kendala dalam dua kategori yaitu kendala umum dan khusus. Adapun dari hasil penelitian yang dilakukan terdapat kendala umum seperti siswa yang kurang disiplin ketika mengikuti pembelajaran di kelas, karakter yang beragam sehingga diperlukan pendalaman karakter yang lebih baik, dan metode pembelajaran yang baru belum tentu memberikan hasil yang memuaskan.

Dari hasil observasi peneliti, ada berbagai kendalakendala khusus yang dihadapi guru Sejarah Kebudayaan Islam dalam pembelajaran. Berikut kendala khusus yang dihadap guru Sejarah Kebudayaan Islam dalam meningkatkan prestasi dan motivasi belajar peserta didik; kurangnya jam pembelajaran SKI; pelajaran Sejarah Kebudayaan Islam yang kurang diminati;dan perbedaan latar belakang pendidikan.

Dari hasil penelitian yang dilakukan, ditemukan bahwa kendala pada umumnya seperti karakter dan minat bakat siswa, sehingga diperlukan kemampuan dan manajemen yang baik agar bisa mengarahkan semua siswa. Terlepas dari kendala yang terjadi, peneliti melihat hal ini adalah sebuah kewajaran yang terjadi dalam sebuah pembelajaran pada umunya. Sehingga yang disesuaikan dengan teori di atas tidak sepenuhnya terjadi di MTs N 9 Sleman karena yang didapatkan adalah kendala pada umunya seperti kenakalan remaja dan kedisiplinan siswa. 


\section{$e^{\text {I-Tarbawj Mukhlis Cahyo Muh Arifin \& Burhan Nudin }}$}

\section{Kesimpulan}

Penerapan kepemimpinan guru SKI dalam meningkatkan prestasi dan motivasi belajar di MTs N 9 Sleman di dalam pembelajaran, yaitu saat pendahuluan guru selalu mengawali dengan salam, berdoa, menanyakan kesuliatan dalam pembelajaran, menanyakan kondisi kabar peserta didik, saat kegiatan inti guru menggunakan media seperti power point, film, dan lain-lain, dan sebelum pembelajaran selesai peserta didik diingatkan kembali materi yang sudah disampaikan dan terakhir peserta didik mengerjakan kumpulan soal dari guru. Proses penerapan kepemimpinan guru SKI di luar pembelajaran yaitu selalu memberikan contoh kepada peserta didik yang baik seperti disiplin, akhlah yang baik serta rajin beribadah. Kendala yang dialami guru SKI dalam meningkatkan prestasi dan motivasi belajar peserta didik diantaranya terbagi menjadi dua kategori, yaitu kendala umum seperti kurang disiplinnya siswa dalam mengikuti pembelajaran, karakter yang beragam, metode baru yang belum tentu memberikan hasil yang memuaskan dan kendala khusus yang dihadapi yaitu kurangnya jam pembelajaran SKI, pelajaran SKI yang kurang diminati oleh peserta didik, dan perbedaan latar belakang pendidikan peserta didik.

\section{Daftar Pustaka}

Abdullah, Burhanuddin. Feformasi Pendidikan di Indonesia dalam Perspektif Pendidikan Islam. Millah Jurnal Studi Agama. Vol IX, No. 2, Februari 2010 
Ariani, Novi. (2015). Pengaruh Gaya Kepemimpinan Demokratis terhadap Disiplin Kerja Karyawan Pada PT.PP.London Sumatera Indonesia, Tbk. Wilayah Bulukumba. Makassar: Skripsi Administrasi Perkantoran FIS UNM.

A.M. Sardiman. (2011). Interaksi dan Motivasi Belajar Mengajar. PT Rajagrafindo : Jakarta.

A.W. Widjaja. 2002. Komunikasi dan Hubungan Masyarakat. Jakarta : PT. Bumi Aksara.

Badeni. (2013). Kepemimpinan dan Perilaku Organisasi. (Bandung : Alfabeta).

Fajri, Awaliatul dkk. "Seterategi Kepemimpinan Kepala Sekolah Dan Kinerja Guru Terhadap Prestasi Belajar Siswa", Tawazun Jurnal Pendidikan Islam, Vol. 12 No. 1, (Juni 2019), hal. 92.

Nanus, Burt. Kepemimpian Visioner. (Prehalindo : Jakarta, 2001).

Harsanto, R. 2007. Pengelolaan Kelas yang Dinamis : Paradigma Baru Pembelajaran Menuju Kompetensi Siswa. Yogyakarta : Kanisius.

Nurhayati, Indah. Efektivitas Kepemimpinan dalam Meningkatkan Mutu Pendidikan Di MTs Al-Muttaqin Tanjung Putus Langkat, Skripsi, 2018.

Kholidah, E.N. \& Alsa, A. (2010). Berfpikir positif untuk menurunkan stres psikologi. Jurnal Psikologi, 39.

Komariah, Aan.(2008). Visionary Leadership: Menuju Sekolah Efektif: (Jakarta: Bumi Aksara)

Kowalski, Robert E. (2007). Terapi Hipertensi. Alih Bahasa: Rani Ekawati. Jakarta. Mizan Pustaka.

M. Ngalim Purwanto. (2004), Administrasi dan Supervisi Pendidikan, Bandung: Remaja Karya.

Rivai, Veithzal. (2009). Manajemen Sumber Daya Manusia Untuk Perusahaan Dari Teori dan Praktek, (Jakarta: Rajawali Press). 


\section{$e^{\text {I-Tarbawj Mukhlis Cahyo Muh Arifin \& Burhan Nudin }}$}

Sardiman. A. M. (2005). Interaksi dan Motivasi Belajar Mengajar. Jakarta: Rajawali Press.

Sidjabat. (1993). Sahabat Gembala. Bandung : Yayasan Kalam Hidup. Hal 11-14

Soekanto, Soerjono. (2006). Sosiologi Suatu Pengantar. Jakarta: Raja Grapindo Persada.

Sugiyono. (2010). Metode Penelitian Kuantitatif Kualitatif dan $R \mathcal{E} D$. Bandung: Alfabeta.

Sugiyono. (2017). Metode Penelitian Pendidikan. Bandung: Alfabeta.

Uno B. Hamzah. (2011). Teori Motivasi dan Pengukurannya Analisis di Bidang Pendidikan, Jakarta: PT. Bumi Aksara.

Werren Bennis Burt Nanus. (2006). Leaders Strategi untuk Mengemban Tanggung Jawab. (PT.Buana Ilmu Populer Kelompok Gramedia: Jakarta.

Fujiarti, Innaha. Upaya Guru Mata Pelajaran Sejarah Kebudayaan Islam dalam Meningkatkan Prestasi Belajar Siswa Mata Pelajaran Sejarah Kebudayaan Isalam di MAN 2, Madiun, Skripsi, 2016.

Kunandar. (2011). Guru Profesional (Implementasi Kurikulum Tingkat Satuan Pendidikan dan Sukses dalam Sertifikasi Guru). Jakarta: Raja Grafindo Persada.

Djamarah, Syaiful Bahri. (2005) Guru dan Anak Didik dalam Interaksi Edukatif Suatu Pendekatan Teoretis Psikologis, Jakarta : Rineka Cipta.

Undang-Undang Peraturan Menteri Agama Republik Indonesia Nomer 16 Tahun 2010 tentang Pengelolaan Pendidikan Agama pada Sekolah. 